we have chosen to determine whether TdR kinase, an early enzyme in the HVH replicative cycle, is present in the CSF of rabbits with $\mathrm{HVH}$ encephalitis. The rabbit model of $\mathrm{HVH}$ encephalitis was utilized to evaluate this hypothesis and to partially characterize the CSF TdR kinase.

Infected rabbit CSF contained significantly more TdR kinase than uninfected rabbit CSF and the enzyme activity was optimal at a $\mathrm{pH}$ intermediate between the optimal $\mathrm{pH}$ for either HV.H or rabbit mononuclear cell TdR kinase. These data suggest that abortive HVH infection occurs in CSF mononuclear cells during the course of HVH encephalitis and that detection of this early enzyme in CSF could be utilized to provide indirect evidence of $\mathrm{HVH}$ central nervous system infection.

\section{REFERENCES}

1. Armstrong, C.: Herpes simplex virus recovered from spinal fluid of suspected case of lymphocytic choriomeningitis. Pub. Health Rep., 58: 16 (1943).

2. Boyum, A.: Isolation of mononuclear cells and granulocytes from human blood. Scand. J. Clin. Lab. Invest. Suppl., 97: 77 (1968).

3. Brunell, P. A., and Dodd, K.: Isolation of herpes virus hominis from cerebrospinal fluid of child with bacterial meningitis and gingivostomatitis. J. Pediat. 65: 53 (1964).

4. Buchan, A., Tuff, S., and Wallia, C.: Failure to demonstrate the interaction of subunits of thymidine kinase in cells simultaneously infected with herpes virus and a kinaseless mutant. J. Gen. Virol., 9: 229 (1970).

5. Buchan, A., and Watson, D. H.: The immunological specificity to thy midine kinases in cells infected by viruses of the herpes group. J. Gen. Virol., 4: 461 (1969).

6. Buchan, A., Watson, D. H., Dubbs, D. R., and Kit, S.: Serologic study of a mutant of herpesvirus unable to stimulate thymidine kinase. J. Virol., 5: 817 (1970).

7. Dayan, A. D., and Stodes, M. I.: Rapid diagnosis of encephalitis by immunofluorescent examination of cerebrospinal fluid cells. Lancet, $i: 177$ (1973).

8. Hunt, B. P., and Comer, E. O. B. Herpetic meningo-encephalitis accompanying cutaneous herpes simplex. Amer. J. Med., 19: 814 (1955).

9. Ives, D. H., Furham, J. P., and Tucker, V. S.: Rapid determination of nucleotide kinase and nucleotidase activities with tritiumlabeled substances. Anal. Biochem., 28: 192 (1969).

10. Klemper, H. G., Haynes, R. E., Shedden, W. I. H., and Watson, D. H.: A virus-specific thymidine kinase in BHK21 cells infected with herpes simplex virus. Virology, 31: 120 (1967).

11. Nahmias, A. J., Alford, C. A., and Korones, S. B. Infection of the newborn with herpesvirus hominis. Advan. Pediat., 17: 185 (1970).

12. Nahmias, A. J., Kibrick, S., and Rosan, R. C.: Viral leukoycyte interrelationships. I. Multiplication of a DNA virus-Herpes simplex-in human leukocyte cultures. J. Immunol., 93: 69 (1964).

13. Pollack, J. D., Somerson, N. L., and Senterfit, L. B.: Characterization and immunogenicity of mycoplasma pneumoniae membranes. Infect. Immun., 2: 326 (1970).

14. Rabinowitz, Y., and Wilhite, B. A.: Thymidine salvage pathway in normal and leukemic leukoyctes with effects of ATP on enzyme control. Blood, 33: 759 (1969).

15. Rabinowitz, Y., Wong, $P_{\text {., }}$ and Wilhite, B. A.: The effect of phy tohemagglutinin on enzymes of thymidine salvage of cultured chronic lymphatic leukemia lymphocytes. Blood, 35: 236 (1970).

16. Sommerville, R. G.: Rapid identification of neurotropic viruses by an immunofluorscent technique applied to crebrospinal fluid cellular deposits. Arch. Virusforschung, 29: 63 (1966).

17. Stalder, H., Oxman, M. N., Dawson, D. M., and Levin, M. J.: Herpes simplex meningitis: Isolation of herpes simplex virus type 2 from cerebrospinal fluid. New Engl. J. Med., 289: 1296 (1973). 18. Reeve Angel, Clifton, N. J.

19. The authors would like to thank William Zaayer for his competent technical assistance.

20. This study was presented in part at the Society for Pediatric Research annual meeting, May 1972, in Washington, D.C.

21. This investigation was supported in part by United States Public Health Service General Research Support Grant no. RR05505 from the Children's Hospital Research Foundation.

22. Requests for reprints should be addressed to: M. D. Hilty, M. D., Children's Hospital, 561 S. 17 th. St, Columbus, Ohio 43205 (USA).

23. Accepted for publication November $20,1974$.
Brain cerebellum cerebrum malnutrition synaptosomes

\title{
Development of $\mathrm{Na}^{+}-\mathrm{K}^{+}$-ATPase in Neonatal Rat Brain Synaptosomes after Perinatal Protein Malnutrition
}

\author{
JAMES Q. KISSANE AND ERVIN J. HAWRYLEWICZ(2 3) \\ Department of Research, Mercy Hospital and Medical Center, Chicago, Illinois, USA
}

\section{Extract}

Four protein dietary groups of rats were used in this study, namely: $27 \%$ casein diet fed throughout gestation and lactation (group $C$-C); $27 \%$ gestation, 10\% lactation (group $C-D$ ); $10 \%$ gestation, $27 \%$ lactation (group $D-C$ ); $10 \%$ throughout gestation and lactation (group $D-D)$. Mean body weight of group $D-D$ at weaning was $19 \mathrm{~g}$ compared with $59 \mathrm{~g}$ for group $C$ - $C$.
The specific activity of $\mathrm{Na}^{+}-\mathrm{K}^{+}$-ATPase in isolated synaptosomes from cerebral and cerebellar tissues increases throughout the lactation period. At 1 and 7 days of age no differences in $\mathrm{Na}^{+}-\mathrm{K}^{+}$-ATPase activity are noted in the brain regions of Groups $C-C$ and $D-D$. At 14 and 21 days, however, the specific $\mathrm{Na}^{+}-\mathrm{K}^{+}$-ATPase activity was significantly reduced in isolated synaptosomes from both brain regions of the protein-deprived group. ATPase activity in cerebellar synaptosomes from dietary exchange groups $(C-D$ and $D-C)$ 
developed to the same extent as that of the control group $(C-C)$ after 21 days of lactation. ATPase activity in the cerebral synaptosomes of the dietary exchange group $(C-D)$ did not develop to the same extent as that in the control group $(C-C)$ and the other dietary exchange group $(D-C)$.

\section{Speculation}

$\mathrm{Na}^{+}-\mathrm{K}^{+}$-activated ATPase plays a fundamental role in synaptic transmission and possibly in transport of neurotransmitters. Synaptosomal ATPase activity increased rapidly in the neonatal rat brain. Inadequate protein nutrition during the fetal and neonatal development period could retard enzyme expression and alter behavior patterns.

Rehabilitative value of administering augmented diets would depend upon the neonatal age and the region of the brain examined. Cerebellar hyperplasia ceases before cerebral hyperplasia; therefore, selected lesions and behavior abnormalities may develop.

The combination of prenatal and postnatal undernutrition severely alters the development of the brain and other organs of the young rat, $(6,16,17)$. The weight of component brain regions, and protein, RNA, and DNA contents of these regions are reduced after undernutrition during gestation and lactation.

The severest effects on total brain development in the neonatal rat are produced by undernutrition during gestation and lactation (18). At the time of weaning the undernourished neonatal rat manifests reduced neuronal and glial cell populations in the cerebrum, cerebellum, and brain stem. Unlike other tissues in the rat, brain cells do not divide significantly after the $21 \mathrm{st}$ day after birth; therefore, permanent deficiency is produced in the undernourished young rat.

Adlard and Dobbing (4) cite impairment of development of neuronal enzymes following undernutrition during gestation and lactation. Acetylcholinesterase (AChe) activity was diminished in mitochondrial preparations from brain stem, forebrain, and olfactory lobes of 21-day-old rats subjected to undernutrition from the 7 th day of gestation. AChe activity in the cerebellum of these rats was relatively unaffected because of the inherently slower development of the enzymes in this region.

Samson and Quinn (14) and Abdel-Latif et al. (1) reported increasing $\mathrm{Na}^{+}-\mathrm{K}^{+}$-ATPase activity in developing brain tissue from normal neonates.

Adlard et al. (3), however, reports that 21-day-old undernourished rats possess a diminished capability for maintaining sodium-potassium gradients in the whole brain. This finding correlates with a decreased activity of $\mathrm{Na}^{+}-\mathrm{K}^{+}$-stimulated $\mathrm{Mg}^{+2}$-ATPase $\left(\mathrm{Na}^{+}-\mathrm{K}^{+}\right.$-ATPase; ATP phosphohydrolase EC. 3.6.1.3) in homogenates of the whole brain.

We investigated several biochemical parameters in the brain in neonatal rats subjected to protein deficiency during gestation and lactation $(9,11)$. We are reporting our current findings regarding the effects of perinatal protein deficiency upon the development of $\mathrm{Na}^{+}-\mathrm{K}^{+}$-ATPase activity in isolated nerve endings from the cerebral and cerebellar region of the brain. These studies were carried out in several experimental stages by adjusting dietary protein intake during the gestation and lactation periods of perinatal development to determine the onset and reversibility of enzyme deficiency.

\section{MATERIALS AND METHODS}

\section{ANIMALS}

Female Sprague-Dawley rats which weighed approximately $200 \mathrm{~g}$ were fed either an ad libitum (19) $10 \%$ casein diet, or a
$27 \%$ casein diet. After 2 days of dietary adjustment, both groups were mated for a period of 21 days. Then, the female rats were isolated and the ensuing birth statistics recorded. All litters were reduced to six neonates.

The survival rate over 21 days is $60 \%$ for the doubly deprived group $(D-D), 90-100 \%$ for the dietary exchange $(D-C)$ and control $(C-C)$ groups, $80-90 \%$ for the dietary exchange group $(C-D)$.

DIET

The four protein dietary groups of animals used in this study are as shown in Table 1.

In the case of the $C-C$ and $D-D$ groups of animals, analyses were performed at the day of birth and 7,14 , and 21 days of age. Groups $C-D$ and $D-C$ were analyzed only on the 21 st day of the lactation period.

\section{SYNAPTOSOME PREPARATION}

On the day of analysis the litter of animals was decapitated. The cerebral and cerebellar regions of the brains were then immediately separated and pooled to insure sufficient material for processing and analysis.

The brain mitochondrial-synaptosomal fraction was prepared by modifying the method of Ozawa (13). The separated brain material was washed in ice-cold mannitol solution containing $0.3 \mathrm{M}$ mannitol, $0.2 \mathrm{mM}$ ethyleneglycol-bis- $(\beta$ aminoethyl ether) $N, N^{\prime}$-tetraacetic acid, and bovine serum albumin, $1 \mathrm{mg} / \mathrm{ml}$. The tissues were homogenized in the same medium using $10 \mathrm{ml} / \mathrm{g}$ tissue. Centrifugation at $600 \times \mathrm{g}$ for 10 min at $4^{\circ}$ removed nuclei and cell debris. The crude mitochondrial-synaptosomal fraction was obtained by centrifuging the supernatant at $10,000 \times \mathrm{g}$ for $10 \mathrm{~min}$ at $4^{\circ}$. The pellet obtained was resuspended in cold mannitol solution and carefully layered on a discontinuous $5-13 \%$ Ficoll gradient (15) and centrifuged at $40,000 \times \mathrm{g}$ for $20 \mathrm{~min}$ at $2^{\circ}$ using a Spinco SW 50.1 rotor. The synaptosomal fraction was removed from the region of 5-13\% interface and diluted with $20 \mathrm{ml}$ cold Tris- $\mathrm{HCl}$ buffer, $0.1 \mathrm{M}, \mathrm{pH} \mathrm{7.4}$. The fraction was centrifuged at $12,000 \times \mathrm{g}$ for $10 \mathrm{~min}$. The final pellet was resuspended in the cold Tris buffer to a concentration of 1.25 $\mathrm{mg}$ protein $/ \mathrm{ml}$.

Electron micrographs of this preparation from 1-day-old rats indicate an enriched content of nerve ending elements with some contamination by mitochondria, nuclei, and axon particles. This preparation was comparable with that reported by Verity (15). At 14 and 21 days of age the electron micrographs showed well developed synaptosomes with a minimum of particulate contamination.

\section{ATPASE ACTIVITY}

Assays of $\mathrm{Na}^{+}-\mathrm{K}^{+}$-stimulated ATPase were carried out by the procedure of Abdel-Latif (2) in a reaction medium containing, at final concentration, adenosine triphosphate, disodium salt (20), $4 \mathrm{mM}$; magnesium chloride, $6 \mathrm{mM}$; Tris buffer, $40 \mathrm{mM}, \mathrm{pH} 7.4$; and $0.25 \mathrm{mg}$ synaptosomal protein. Sodium chloride and potassium chloride were added to provide a final concentration of 150 and $20 \mathrm{mM}$, respectively.

Table 1. Nutritional schedule

\begin{tabular}{clc}
\hline $\begin{array}{c}\text { Gestation } \\
(21 \text { days })\end{array}$ & \multicolumn{1}{c}{$\begin{array}{c}\text { Lactation } \\
\text { (21 days) }\end{array}$} & Group \\
\hline $27 \%$ Casein (control) & $27 \%$ Casein (control) & $C-C$ \\
$27 \%$ Casein (control) & $10 \%$ Casein (deficient) & $C-D$ \\
$10 \%$ Casein & $27 \%$ Casein & $D-C$ \\
$10 \%$ Casein & $10 \%$ Casein & $D-D$ \\
\hline
\end{tabular}


Ouabain (21), $1 \mathrm{mM}$ final concentration, was used as a specific inhibitor of $\mathrm{Na}^{+}-\mathrm{K}^{+}$-ATPase. Aliquots of reaction mixture which were deproteinized with tricholoroacetic acid were analyzed for inorganic phosphate by the Fiske-SubbaRow method (7). Synaptosomal protein content was determined by Lowry's method (12). All results are expressed as micromoles of inorganic phosphate liberated per milligram of synaptosomal protein per hour at $30^{\circ}$.

\section{RESULTS}

\section{GROWTH RATE}

The rate of increase in body weight for neonates on the experimental diets is shown in Figure 1. Twenty-one days after birth, neonates which had been deprived of protein during gestation and lactation $(D-D)$ attained a mean body weight of $19 \mathrm{~g}$ compared with a mean weight of $59 \mathrm{~g}$ attained by control neonates $(C-C)$. Neonates whose diets increased from a $10 \%$ to a $27 \%$ protein content $(D-C)$ had a mean body weight of $53 \mathrm{~g}$ after 21 days. The weight averages after 21 days are significantly different from each other; however, the increase in body weight for the dietary exchange group $(D-C)$ approaches that of the control group $(C-C)$.

On the other hand, animals receiving a $27 \%$ gestational diet which was reduced to a $10 \%$ diet during lactation $(C-D)$ exhibited a mean body weight of $29 \mathrm{~g}$ at the end of 21 days. This 29-g value approaches that of the doubly deprived neonates $(D-D)$, yet is statistically different.

\section{$\mathrm{Na}^{+}-\mathrm{K}^{+}-$ATPASE ACTIVITY}

The specific activity of synaptosomal $\mathrm{Na}^{+}-\mathrm{K}^{+}$-ATPase increases in the two brain regions for both the $10 \%(D-D)$ and $27 \%(C-C)$ protein dietary groups over the period of $1-21$ days (Fig. 2). The difference in values between the two diet groups at 1 day and at 7 days is insignificant. However, the specific activity is significantly lower in the cerebral and cerebellar region of the protein-malnourished animal at 14 days (cerebrum, $P=0.0172$; cerebellum, $P=0.0310$ ) and at 21 days (cerebrum, $P=0.0188$; cerebellum, $P=0.0001$ ).

The values obtained in the case of 21-day-old animals maintained on reversed diets are of interest. With respect to the cerebellar regions of the brain (Fig. 3), it will be noted that the $\mathrm{Na}^{+}-\mathrm{K}^{+}$-ATPase values derived from all dietary exchange groups are comparable with those obtained from animals maintained on the constant $27 \%$ casein diet $(C-C)$ within the limits of the standard deviation. These same groups, however, demonstrate a significantly higher activity than do those animals maintained on a protein-deprived diet throughout gestation and lactation.

The development of $\mathrm{Na}^{+}-\mathrm{K}^{+}$-ATPase activity in the cerebral synaptosomes of animals placed on reversed diets is dissimilar to that obtained in the case of the cerebellum (Fig. 3). No significant difference ensues in the activity level of neonates transferred to $10 \%$ diets $(C-D)$ compared with the doubly deprived neonates $(D-D)$. However, $\mathrm{Na}^{+}-\mathrm{K}^{+}$-ATPase activity in gestationally undernourished neonates transferred to $27 \%$ protein diets $(D-C)$ develops to the same extent as that of the control group $(C-C)$.

\section{DISCUSSION}

The synaptosomes, which are broken fragments of nerve ending structures recovered by centrifugal techniques, provide a basis for specific study of a limited number of important neuronal biochemical functions. One of these functions, $\mathrm{Na}^{+}-\mathrm{K}^{+}$-stimulated ATPase activity, plays an important role in maintaining the ionic gradients essential for nerve impulse conduction.

The activity of $\mathrm{Na}^{+}-\mathrm{K}^{+}$-stimulated ATPase develops progressively in synaptosomal fractions of the cerebrum and

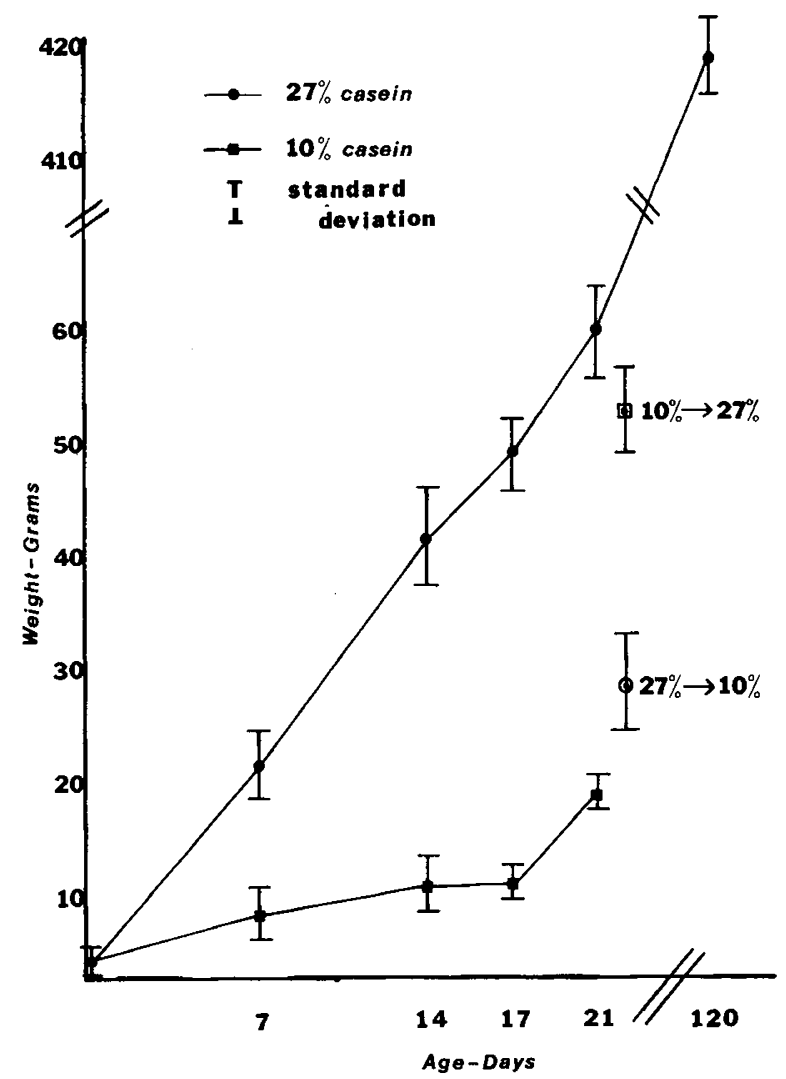

Fig. 1. Growth curves of neonates derived from dams maintained throughout gestation and lactation on casein diets of $10 \%(--)$ or $27 \%(-\bullet-)$. Points designated $(10 \% \rightarrow 27 \%)$ and $(27 \% \rightarrow 10 \%)$ indicate maternal diet alteration at birth of litter.

cerebellum over the 21 -day postnatal period. The development of this enzyme in those neonates maintained on low protein diets during gestation and lactation is significantly impaired as reflected by the lower specific activities of this enzyme in synaptosomal fractions derived from the two brain regions at 14 and 21 days.

Our findings confirm and extend the observations of Dobbing (3). Although the manner of diet in this study differs from that used by Dobbing, nevertheless the results are similar. By isolating the nerve ending particles of cerebral and cerebellar neurons, we have been able to show that the specific activity of $\mathrm{Na}^{+}-\mathrm{K}^{+}$-ATPase in both regions is diminished as a result of gestational and lactational protein insufficiency. Dobbing speculates that the diminished $\mathrm{Na}^{+}-\mathrm{K}^{+}$-ATPase activity in his mitochondrial-synaptosomal preparation from 21-day-old undernourished rats may be caused by a lowered specific activity and possibly to a reduced number of synaptosomes. Evidence for decreased synaptogenesis has been cited by Bass (5).

The effect of gestational protein insufficiency upon $\mathrm{Na}^{+}-$ $\mathrm{K}^{+}$-ATPase activity appears to be reversible after birth in the cerebrum and in the cerebellum by augmenting the mother's diet with protein during the 21-day lactation period. Equally important is the fact that protein insufficiency imposed during lactation upon gestationally well nourished neonates does not diminish the specific $\mathrm{Na}^{+}-\mathrm{K}^{+}$-ATPase activity in the cerebellar synaptosomes. Conversely, the activity is reduced in the cerebrum under the same conditions. This difference in enzyme development between the cerebrum and cerebellum reflects a susceptibility difference which alters the development of the nerve endings in the two brain regions.

In view of the apparent difference in susceptibility to malnutrition during lactation it may be suggested that synaptic development in the cerebrum and cerebellum occur at different rates. Within the first week of neonatal life, the 


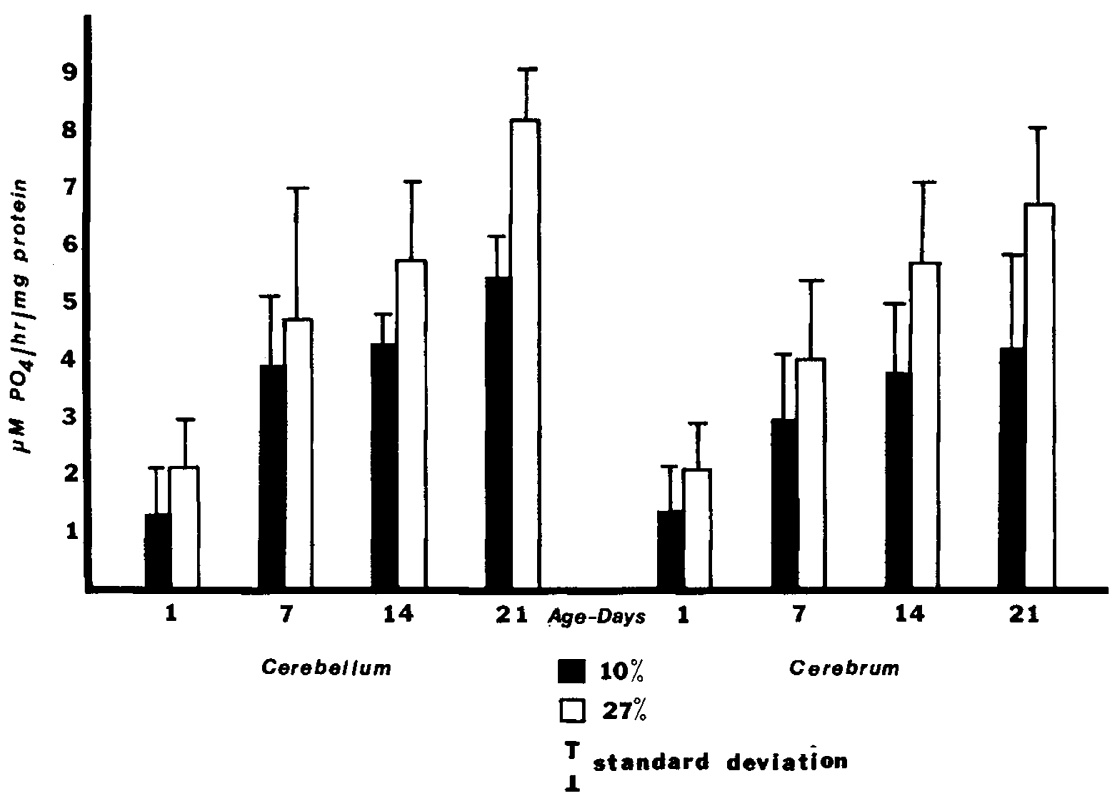

Fig. 2. $\mathrm{Na}^{\mathrm{t}}-\mathrm{K}^{+}$-stimulated, $\mathrm{Mg}^{++}$-dependent ATPase activity in isolated synaptosomes from neonatal cerebellar and cerebral tissue as a function of age and maternal diet ( $10 \%$ or $27 \%$ casein).

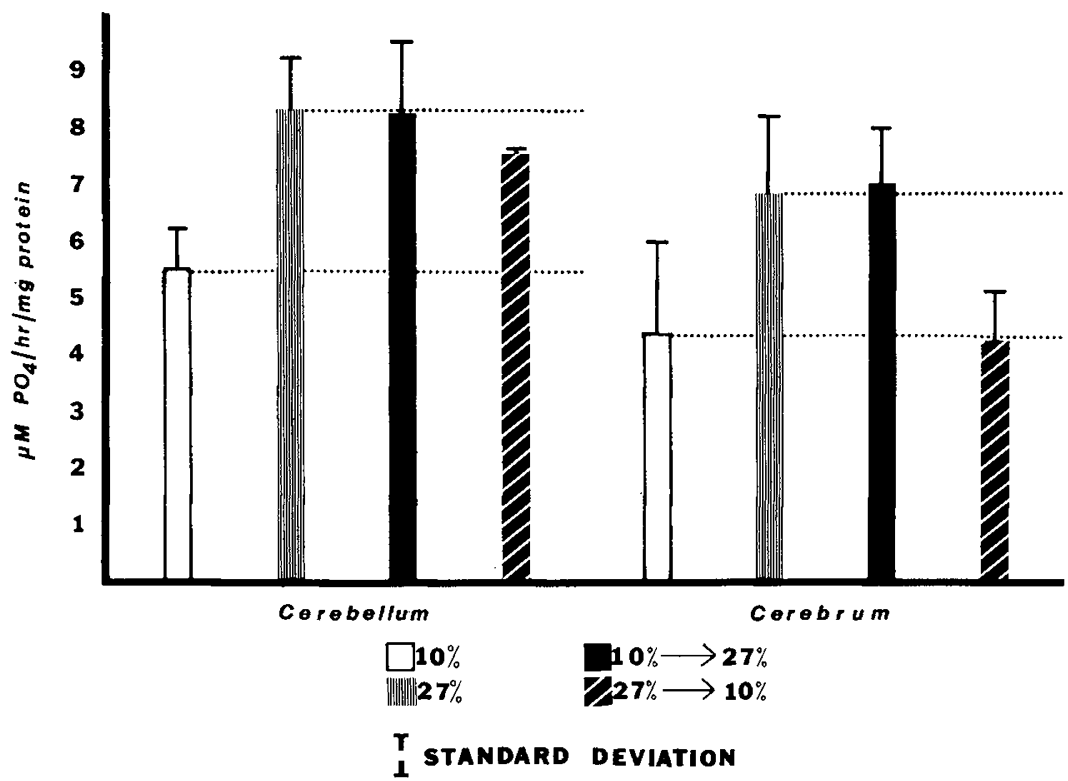

Fig. 3. $\mathrm{Na}^{+}-\mathrm{K}^{+}$-ATPase-stimulated, $\mathrm{Mg}^{+}$-dependent ATPase activity in isolated synaptosomes from neonatal cerebellar and cerebral tissue at 21 days of age. Maternal gestation diets were altered at the time of birth and maintained throughout lactation (e.g., 10\% $\rightarrow 27 \%$ casein).

synaptic terminals in the cerebellum are fully developed and therefore not affected by maternal dietary inadequacies. Conversely, the cerebrum undergoes axon arborization continuously as a function of external stimuli (8). Protracted exposure to protein-inadequate diets affects the extent of synaptogenesis (5), and apparently the specific enzyme activity within the synaptosomes.

Previous studies (10) that we conducted demonstrated a significant reduction in the rate of ADP utilization (i.e., Q(ADP); nanomoles per milligram of mitochondrial protein per minute) in malnourished rat brain at 7 and 14 days of age. Contrary to expectations, ATP concentrations were significantly elevated at the same ages. Decreased $\mathrm{Na}^{+}-\mathrm{K}^{+}$-ATPase specific activity in the malnourished animals may contribute to this effect.

Augmented protein diets administered to malnourished neonates immediately after birth allow for normal development of synaptosomal $\mathrm{Na}^{+}-\mathrm{K}^{+}$-ATPase specific activity.
Studies are in progress to determine the reversibility after weaning ( 21 days of age).

\section{SUMMARY}

Young rats of dams maintained on low protein diets during gestation and lactation demonstrate a significantly decreased level of $\mathrm{Na}^{+}-\mathrm{K}^{+}$-ATPase activity in synaptosomal preparations from the cerebrum and cerebellum. Changes in the specific activity for this enzyme are significant at 14 and 21 days after birth.

The adverse effects of gestational protein malnutrition are reversible with protein augmentation during lactation. Gain in body weight and the specific activity of synaptosomal $\mathrm{Na}^{+}-\mathrm{K}^{+}$-ATPase from cerebellum are both enhanced to normal values. Cerebral $\mathrm{Na}^{+}-\mathrm{K}^{+}$-ATPase activity is also increased to within normal values.

Lactational protein deficiency imposed upon gestational 
well nourished neonates does not affect the specific activity of synaptosomal $\mathrm{Na}^{+}-\mathrm{K}^{+}$-ATPase from the cerebellum but does appear to inhibit the development of cerebral ATPase. Body weight gain in these animals is greatly decreased.

\section{REFERENCES AND NOTES}

1. Abdel-Latif, A. A., Smith, J. P., and Ellington, E. P.: Subcellular distribution of sodium-potassium adenosine triphosphatase, acetylcholine and acetylcholinesterase in developing rat brain. Brain Res., 18: 441 (1970).

2. Abdel-Latif, A. A., Smith, J. P., and Hedrick, N.: Adenosine triphosphate and nucleotide metabolism in synaptosomes of rat brain. J. Neurochem., 17: 391 (1970).

3. Adlard, B. P. F., DeSouza, S. W., and Dobbing, J.: Effects of growth retardation and asphyxia on brain electrolytes and on glycolysis in developing rats. Pediat. Res., 7: 494 (1973).

4. Adlard, B. P. F., and Dobbing, J.: Vulnerability of developing brain. V. Effects of fetal and postnatal undernutrition on regional brain enzyme activities in three-week-old rats. Pediat. Res., 6: 38 (1972).

5. Bass, N. H., Netsky, M. G., and Young, E.: Effect of neonatal malnutrition on developing cerebrum. I. Microchemical and histologic study of cellular differentiation in the rat. Arch. Neurol., 23: 289 (1970)

6. Fish, I., and Winick, M.: Cellular growth in various regions of the developing rat brain. Pediat. Res., 3: 407 (1969).

7. Fiske, C. H., and SubbaRow, Y.: Colorimetric determination of phosphorous. J. Biol. Chem., 66: 375 (1925).

8. Globus, A., Rosenzweig, M. R., and Bennett, E. L., et al.: Effects of differential experience on dendritic spine counts in rat cerebral cortex. J. Comp. Physiol. Psychol., 82: 175 (1973).

9. Hawrylewicz, E. J., and Kissane, J. Q.: Studies on neonatal brain adenine nucleotide levels as a function of protein restricted diets

Copyright $\odot 1975$ International Pediatric Research Foundation, Inc. and age. Report to the American Society for Neurochemistry, Columbus, Ohio, March 13, 1973.

10. Hawrylewicz, E. J., and Kissane, J. Q., and Heppner, C. A.: Effect of maternal protein malnutrition on perinatal brain mitochondria function. Nutr. Rep. Int., 4: 279 (1971).

11. Kissane, J. Q., and Hawrylewicz, E. J. Effect of maternal protein malnutrition upon the development of synaptosomal $\mathrm{Na}^{+}-\mathrm{K}^{+}$ATPase activity in neonatal rats. Fed. Proc., 32: 902 (1973).

12. Lowry, O. H., Rosebrough, N. J., Farr, H. L., and Randall, R. J.: Protein measurement with the Folin phenol reagent. J. Biol. Chem., 193: 265 (1951).

13. Ozawa, K., Seta, K., Takeda, H., et al.: On the isolation of mitochondria with high respiratory control from rat brain. $J$. Biochem. (Tokyo), 59: 501 (1966).

14. Samson, F. E., and Quinn, D. J.: $\mathrm{Na}^{+}-\mathrm{K}^{+}$-activated ATPase in rat brain development. J. Neurochem., 14: 421 (1967).

15. Verity, M. A.: Cation modulation of synaptosomal respiration. $J$. Neurochem., 19: 1305 (1972).

16. Winick, M.: Malnutrition and brain development. J. Pediat Res., 74: 667 (1969).

17. Winick, J.: Cellular growth during early malnutrition. Pediatrics, 47: 969 (1971).

18. Zamenhof, S., van Marthens, E., and Margolis, F. E.: DNA (cell number) and protein in neonatal brain: Alteration by maternal dietary protein restriction. Science, 160: 3825 (1968).

19. Nutritional Biochemical Co., Cleveland, Ohio.

20. Cabiochem, LaJolla, Calif.

21. Sigma Chemical Co., St. Louis, Mo.

22. This research was supported by The John A. Hartford Foundation, Inc., New York.

23. Requests for reprints should be addressed to: E. J. Hawrylewicz, Ph.D., Department of Research, Mercy Hospital and Medical Center, Stevenson Expressway at King Dr., Chicago, Ill. 60616 (USA).

24. Accepted for publication November 25, 1974.

Printed in U.S.A.

Pediat. Res. 9: 150-153 (1975)

Bilirubin deoxyribonucleic acid riboflavin hyperbilirubinemia

\title{
In Vitro Studies of Effects of Light and Riboflavin on DNA and HeLa Cells
}

\author{
WILLIAM T. SPECK, ${ }^{(23)}$ CHANG CHIU CHEN, AND HERBERT S. ROSENKRANZ \\ Departments of Pediatrics and Microbiology, College of Physicians and Surgeons, Columbia University, \\ New York, New York, USA
}

\section{Extract}

The widespread use of phototherapy for neonatal hyperbilirubinemia has caused some concern since substances other than bilirubin may be photoactivated. The toxic properties of these photoactivated substances might prove to be more harmful to the neonatal infant than bilirubin. The purpose of the present study was to investigate the effect of photoactivated riboflavin in low concentration, on purified DNA. The results demonstrate extensive changes in the structure of DNA (see Table 1) manifested by (1) a change in the peak absorbance in the ultraviolet, (2) a decrease in the temperature of the thermal helix-coil transition, (3) a slight decrease in the sedimentation coefficient, and (4) an increase in the buoyant density values (1.704-1.709). These observations are consist- ent with the interpretation that there has been an alteration of one of the base moieties with minimal cleavage of the phosphodiester linkages. Results with human cells in tissue culture indicate that a similar photodynamic effect of riboflavin on the DNA occurs in living cells.

\section{Speculation}

In view of the known relation between the ability of a variety of agents to modify DNA on the one hand and the potential to induce mutation and cancer on the other, the present results suggest that riboflavin supplementation as an adjunct to phototherapy for hyperbilirubinemia requires more thorough evaluation. 